\title{
Prognostic Significance of Bcl-2, C-Myc, Survivin and Tumor Grade in Synovial Sarcoma
}

\author{
Sinovyal Sarkom Olgularında Bcl-2, C-Myc, Survivin ve \\ Tümör Derecesinin Prognostik Değeri
}

\author{
Derya DEMIR', Banu YAMAN², Yavuz ANACAK³ ${ }^{3}$ Burçin KEÇECi ${ }^{4}$, Gülşen KANDILOĞLU², Taner AKALIN² \\ 'Department of Pathology, Manisa State Hospital, MANISA, TURKEY, \\ Departments of ${ }^{2}$ Pathology, ${ }^{3}$ Radiation Oncology and ${ }^{4}$ Orthopaedics and Traumatology, Ege University, Faculty of Medicine, IZMIR, TURKEY
}

\begin{abstract}
Objective: We aimed to determine the prognostic value of bcl-2, c-myc and survivin in synovial sarcoma cases and to evaluate the relationship between the conventional morphological findings with prognosis.

Material and Method: In this study, we evaluated 81 synovial sarcoma cases referred to our tertiary tumor center during a period of 20 years. We applied bcl-2, c-myc and survivin immunohistochemically and investigated the relationship with prognosis for those 65 cases with follow-up. The relationship between the conventional morphological findings (mitosis, necrosis, grade) with prognosis was also investigated.
\end{abstract}

Results: Five-year disease free survival rate was $44 \%$ and ten-year progression free survival rate was $38 \%$, reflecting the aggressive behavior of synovial sarcoma. Tumor grade (according to FNCLCC) was the most significant prognostic input in this study. We obtained a significant difference between grade II (40 cases) and grade III ( 24 cases) group regarding progression-free survival and overall survival $(\mathrm{p}<0.001$ and $\mathrm{p}<0.001$ respectively). Grade II was divided into two groups according to mitotic index and necrosis (grade IIa and IIb) and there was a significant difference between them regarding prognosis $(p=0.013$ for progression free survival, $p=0.003$ for overall survival). There was a significant relationship between bcl-2 negative plus focally weak positive cases ( 9 cases) and focally strong cases ( 21 cases) and diffuse strong cases ( 35 cases) $(\mathrm{p}=0.042$ and $\mathrm{p}=0.016$ respectively). There was a significant relation between $\mathrm{c}$-myc negative cases ( 25 cases) and nuclear positive cases (17 cases) regarding overall survival ( $\mathrm{p}=0.043$ ) and between $\mathrm{c}$-myc negative cases and cytoplasmic positive cases ( 23 cases) regarding progression free survival $(\mathrm{p}=0.05)$. The relation between survivin and prognosis was not significant.

Conclusion: Tumor grade was the most significant prognostic parameter in this study. The grade IIa group (with less than 10 mitoses in $10 \mathrm{HPF}$, without necrosis) had a better prognosis than both the grade IIb and III groups. The grade IIb group was closer to grade III regarding the prognosis. Bcl-2 and c-myc (nuclear and/or cytoplasmic) immunohistochemical positivity had prognostic value but this finding has to be confirmed by large series.

Key Words: Soft tissue neoplasm, Prognosis, Immunohistochemistry, $\mathrm{Bcl}-2, \mathrm{Myc}$

(Turk Patoloji Derg 2014, 30:55-65)

Received : 18.05.2013 Accepted : 30.12.2013

\section{öz}

Amaç: Bcl-2, c-myc ve survivinin sinovyal sarkom olgularında prognostik değerini saptamak ve konvansiyonel morfolojik bulguların prognoz ile ilişkisini değerlendirmeyi amaçladık.

Gereç ve Yöntem: Bu çalışmada, yaklaşık 20 yılda üçüncü basamak tümör merkezimize başvuran 81 sinovyal sarkom olgusunu değerlendirdik. İmmünhistokimyasal yöntemle bcl-2, c-myc ve survivin çalışarak takibi bilinen 65 olguda prognoz ile ilişkisin araştırdık. Konvansiyonel morfolojik bulgular (mitoz, nekroz, derece) ile prognoz arasındaki ilişki de araştırıldı.

Bulgular: Bu çalıșmada; beș yıllık hastalıksız sağkalım oranı \%44, 10 yıllık hastalıksız sağkalım oranı \%38 olarak bulunmuştur ki sinovyal sarkomun agresif davranışını yansıtmaktadır. Bu çalışmada tümör derecesi (FNCLCC'ye göre) en anlamlı prognostik belirleyiciydi. Derece II (40 olgu) ile, derece III grubu (24 olgu) arasında hastalıksız sağkalım ve sağkalım açısından anlamlı fark saptandı (sırasıyla $\mathrm{p}<0,001 \mathrm{ve} \mathrm{p}<0,001)$. Derece II grubu mitotik indeks ve nekroz bulgularına göre iki gruba ayrıldı (IIa ve IIb) ve iki grup arasında prognoz açısından fark saptandı (hastalıksız sağkalım için $\mathrm{p}=0,013$, sağkalım için $\mathrm{p}=0,003)$. Bcl-2 negatif ve fokal pozitif olgular ( 9 olgu) ile fokal güçlü pozitif (21 olgu) ve yaygın güçlü pozitif (35 olgu) olgular arasında hastalıksız sağkalım açısından anlamlı ilişki saptandı (sirasiyla $\mathrm{p}=0,042$ ve $\mathrm{p}=0,016)$. C-myc negatif olgular ile ( $25 \mathrm{olgu}$ ) nükleer pozitif olgular (17 olgu) arasında sağkalım açısından, c-myc negatif olgular ile sitoplazmik pozitif olgular (23 olgu) arasında ise hastalıksız sağkalım açısından anlamlı fark saptandı (sırasıyla $\mathrm{p}=0,043$ ve $\mathrm{p}=0,05)$. Survivin ekspresyonunun prognoz ile ilişkisi anlamlı değildi.

Sonuç: $\mathrm{Bu}$ çalışmada, tümör derecesi en anlamlı prognostik belirleyiciydi. Derece IIa grubu (Nekrozu olmayan ve 10 BBA'da 10 dan az mitoz gösteren grup) prognoz açısından hem derece III hem de IIb grubundan daha iyi prognoza sahipti. Derece IIb grubu prognoz açısından derece III'e daha yakındı. Bcl-2 ve c-myc (nükleer ve/veya sitoplazmik) immünhistokimyasal pozitifliği prognoz ile ilişkilidir ancak bu bulgunun daha geniş seriler ile teyit edilmesi gereklidir.

Anahtar Sözcükler: Yumuşak doku tümörü, Prognoz, İmmünhistokimya, Bcl-2, Myc

Correspondence: Taner AKALIN

Ege Üniversitesi, Tip Fakültesi, Patoloji Anabilim Dalı, IZZMİR, TURKEY

E-mail: taner.akalin@ege.edu.tr Phone: +90 5336196776 


\section{INTRODUCTION}

Malignant soft tissue tumors can cause high mortality and morbidity with local recurrences and systemic metastases. Synovial sarcoma makes up 5 to $10 \%$ of malignant soft tissue tumors. It is typically seen at the thigh, knee or foot in the adolescent-young adult period. Histologically, it has two major types as biphasic and monophasic. The monophasic type largely consists of the fibrous type. Poorly differentiated synovial sarcoma may develop with the progression of these histological types. The biphasic type is usually histologically recognizable but the help of immunohistochemical (IHC) markers is required for the diagnosis of the monophasic fibrous and poorly differentiated types (1). Pancytokeratin and epithelial membrane antigen are IHC determinants used for the diagnosis of synovial sarcoma. Some studies report that cytokeratin 7 is more specific for synovial sarcoma (2). The IHC marker TLE-1 with high sensitivity for synovial sarcoma has been used in some recent studies (3). However some studies report the specificity as low (4). The gold standard for the diagnosis of synovial sarcoma is showing the specific translocation ( $t(X ; 18)$ (SYT-SSX)) (5).

The prognosis of synovial sarcomas is generally poor and the 5- and 10-year survival rates have been reported as 36-76\% and $20-63 \%$ respectively $(1,6-11)$. The factors associated with a good prognosis are younger age (younger than 15 or 20 years of age), small tumor size (smaller than 5 or $7 \mathrm{~cm}$ ), distal extremity location, low tumor stage and appropriate excision of the tumor. Having less-differentiated areas in the tumor, presence of tumor necrosis, and high mitotic activity ( $\geq 10$ mitoses/10 HPF) have been reported as negative morphological prognostic parameters $(1,6-12)$.

The immune expressions of bcl-2, c-myc and survivin in different types of sarcoma and synovial sarcoma cases and their relationship with the prognosis have previously been investigated (13-17). Our aim in this study was to immunohistochemically evaluate the relationship between bcl-2, c-myc, survivin expression and the prognosis of synovial sarcoma because literature findings on the relationship of bcl-2 and c-myc immune expression with the prognosis are not clear. In addition, the relationship between conventional morphological parameters and prognosis was investigated.

\section{MATERIAL and METHODS}

A total of 81 cases who had pancytokeratin or EMA positivity and were suitable for immunohistochemistry (IHC) evaluation among the cases diagnosed with or were thought to indicate synovial sarcoma at our center between 1982 and 2010 were included in the study.
The general information, follow-up durations and the information regarding the disease outcomes (recurrence, metastasis, survival data, etc.) of the cases were obtained from the Orthopaedics and Traumatology Department records, Radiation Oncology Department records, hospital records, and Cancer Monitoring and Control Centre (KİDEM) records.

The WHO (for histological type) and FNLCC (French National Cancer Center) criteria were used as the basis for determining grade of the tumor (differentiation, mitotic index and necrosis) (18). The histological type was evaluated in four groups as epithelial predominant, biphasic, monophasic fibrous and poorly differentiated (Figure 1,2). All cases received three points for tumor differentiation during the grading (1). Mitoses were counted at $10 \mathrm{HPF}$ for mitotic activity. The Nikon Eclipse 80i microscope was used. During scoring, 1 point was given for 0-9 mitoses, 2 points for 10-19 mitoses and 3 points for 20 or more mitoses. Cases without necrosis were given 0 points, cases with less than $50 \%$ necrosis 1 point and cases with more than $50 \%$ necrosis 2 points. Cases with a score of 4 points were evaluated as grade IIa, 5 points as grade IIb and 6 or more points as grade III.

Five micron thick serial sections were obtained from the paraffin-embedded blocks belonging to the selected suitable preparations fixed with formalin to study cytokeratin 7, bcl2, c-myc and survivin with the IHC method on positively

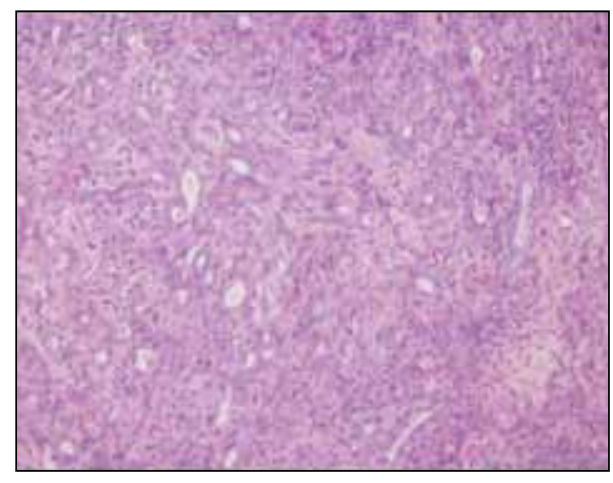

Figure 1: Synovial sarcoma, biphasic type. Epithelial component that occasionally forms fusiform gland-like structures among the fusiform spindle cells (H\&E, x200).

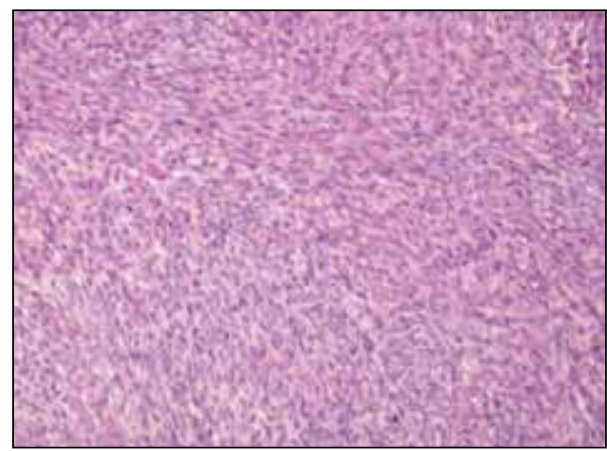

Figure 2: Synovial sarcoma, monophasic fibrous type. Cellular bundle structures created by monotonous spindle-fusiform cells $(\mathrm{H} \& \mathrm{E}$, $\mathrm{x} 100$ ). 
charged slides and one for hematoxylin-eosin staining. The cytokeratin 7 (clone OVTL 12-30, Santa Cruz, 1:100 dilution), bcl-2 (clone 100, Santa Cruz, 1:50 dilution), c-myc (clone 9E10, Santa Cruz, 1: 25 dilution) and survivin (clone SPM331, Santa Cruz, 1:50 dilution) primary antibodies were investigated with IHC examination in the sections. The biotin-free, HRP multimer -based, hydrogen peroxide substrate and 3,3'-diaminobenzidine tetrahydrochloride (DAB) chromogen containing ultraView ${ }^{\text {tm }}$ Universal DAB Detection Kit (Catalog number 760-500, Ventana Medical Systems, Tucson, AZ) and a full automated immunohistochemistry staining device (Ventana BenchMark XT, Ventana Medical Systems, Tucson, AZ) were used as the IHC staining system.

Tissue profiles were taken on electrostatically charged slides (X-traTM, Surgipath Medical Industries, Richmond, Illinois, USA) and dried at $60^{\circ} \mathrm{C}$ for at least two hours. The whole IHC staining process including deparaffinization and antigen revealing procedures were performed at the BenchMark XT and fully automated IHC staining device. Only the primary antibodies cytokeratin 7 (OVTL 12-30), bcl-2 (100), c-myc (9E10) and survivin (SPM331) were manually placed as drops and incubated at $37{ }^{\circ} \mathrm{C}$ for 32 minutes. The counter staining of the sections for which the counter staining was performed with hematoxylin and bluing solution in the device was followed by dehydration after which the sections were made transparent with xylene and the process was concluded with manual coverslip closure.

Cytoplasmic positivity as well as the diffuseness of the staining for bcl-2 were semi-quantitatively evaluated as diffuse $(\geq 50 \%)$ or focal (less than 50$)$ and the severity of the staining as 1 or 2 positive. Statistical evaluation was performed on three groups as negative focal faint positive, focal strong positive, and diffuse strong positive.

Cytoplasmic or nuclear positivity (more than $5 \%$ positivity) as well as the diffusion of c-myc were semi-quantitatively evaluated as diffuse (50\% and over) or focal (less than 50\%) and the severity of the staining as 1 or 2 positive. Statistical evaluation was performed on a total of three groups as a negative group, cytoplasmic positive group and nuclear positive group.

Cytoplasmic positivity and/or nuclear positivity (more than $5 \%$ positivity) as well as the diffuseness of the staining for survivin were semi-quantitatively evaluated as diffuse (50\% and over) and focal (less than 50\%) and the severity of the staining as 1 and 2 positive and the statistical evaluation was performed on a total of three groups as negative group, nuclear evident stained group and cytoplasmic evident stained group.

Statistical analysis was performed with the SPSS (Version 15.0) package software "Kaplan-Meier" survival analysis and "Cox Regression" analysis were used in the study. A p value below 0.05 was considered significant for the analyses.

\section{RESULTS}

The 81 cases consisted of 42 (51.9\%) males and 39 (48.1\%) females. The age range was 13 to 71 years and the mean age 33.6 \pm 14.9 years. The tumor location was known in 80 cases and was the lower extremity in $53(65.4 \%)$, upper extremity in $12(14.8 \%)$, the torso in $10(12.3 \%)$, the head and neck in 3 (3.7\%) and intra-abdominal in 2 (2.5\%). The tumor diameter range was 1 to $23 \mathrm{~cm}$ and the mean tumor diameter was $7.7 \pm 4.3 \mathrm{~cm}$.

Pancytokeratin or EMA positivity was present in all cases on immunohistochemical evaluation. A positive result was obtained in 54 cases and a negative result in 27 cases with cytokeratin 7 .

Follow-up information was present in $65(80.2 \%)$ of the 81 cases. No local recurrence or metastasis was found in 26 $(40 \%)$ of these 65 patients. Nine (14\%) had local recurrence but no metastasis. Five $(8 \%)$ had local recurrence and metastasis. Twenty-five (38\%) had recurrence and/or metastasis and died because of the tumor. The mean diseasefree survival duration was $34.2 \pm 39.4$ months in cases with local recurrence or metastasis and $89.5 \pm 69.4$ months in cases with no local recurrence or metastasis. The mean disease-free survival duration was $111.8 \pm 16.1$ months. The disease-free survival rate was $44 \%$ for five years and $38 \%$ for 10 years. The survival rate was $57 \%$ for five years and $48 \%$ for 10 years. The survival duration range in the 40 live cases among the 65 cases where follow-up could be found was 2 to 264 months and the mean survival duration was $82.9 \pm 68.2$ months. The survival duration range of the 25 cases who died was 12 to 132 months and the mean survival duration was $35.3 \pm 25.8$ months. The mean survival duration of all cases with follow up was $150.6 \pm 16.8$ months.

The relationship of gender and age distribution parameters with disease-free survival or survival duration was not statistically significant.

The distribution of histological subtypes in the 81 cases was epithelial predominant in two (2.5\%), biphasic in $15(18.5 \%)$, monophasic fibrous in $60(74.1 \%)$ and poorly differentiated in $4(4.9 \%)$ cases. No local recurrence and/or metastasis was found in the two epithelial predominant cases and both were alive. Local recurrence and/or metastasis was present in 11 
of 14 biphasic cases (78.6\%) and absent in 3 (21.4\%). Eight of fourteen biphasic type cases (57.1\%) were alive while six (42.9\%) had died. Local recurrence and/or metastasis was found in 24 of 45 monophasic fibrous type cases (53.3\%) and was absent in 21 (46.7\%). 29 of the monophasic fibrous type cases (64.4\%) were alive and $16(35.6 \%)$ had died. Local recurrence and/or metastasis was detected in all of the four poorly differentiated synovial sarcoma cases. One (25\%) was alive and three (75\%) had died. Although the disease-free survival and survival durations were shorter in the biphasic type synovial sarcoma cases compared to the monophasic fibrous type, this difference was not statistically significant.

The mean number of mitosis was $7.8 \pm 7.8$ in the 26 cases with no local recurrence or metastasis. The mean number of mitoses was $14 \pm 9.4$ in the 29 cases with local recurrence and/or metastasis. The relationship between mitosis and disease-free survival was statistically significant $(\mathrm{p}=0.01)$. The number of mitoses in the 40 cases who were alive was $8.9 \pm 8.5$. The number of mitoses in the 25 cases who died was $15.6 \pm 9.2$. The relationship between mitosis and survival was statistically significant $(\mathrm{p}=0.01)$.

Necrosis was evaluated in 64 (79\%) of 81 cases. 17 (21\%) cases were excluded from the evaluation as they contained post-treatment changes associated with neoadjuvant therapy. No necrosis was found in 39 (60.9\%) of the 64 cases. Necrosis under $50 \%$ was observed in 25 (39.1\%) cases. The mean survival duration was $217.3 \pm 18.8$ months and the mean disease-free survival duration $146.2 \pm 22.1$ months in the group without necrosis when evaluated in 50 of the 64 cases with follow-up. The mean survival duration was $60.4 \pm 12.2$ months and the mean disease-free survival duration $45 \pm 10.5$ months in the group with necrosis. The relationship of the necrosis status of the tumor with survival duration and disease-free survival duration was statistically significant $(\mathrm{p}<0.001$ and $\mathrm{p}=0.0013$ respectively).

Grading could be performed in 64 (79\%) of 81 cases. 17 (21\%) cases were excluded from the evaluation as they contained post-treatment changes associated with neoadjuvant therapy. Of the 64 cases, 40 (62.5\%) were evaluated as grade II and $24(37.5 \%)$ as grade III. The disease-free survival duration was $192 \pm 24$ months in the grade IIa group, 56 \pm 13 months in the grade IIb group and $36 \pm 9$ months in grade III group at the evaluation performed on 50 patients with follow-up out of 64 patients. The relationship between grade IIa and grade IIb and between grade IIa and grade III was statistically significant in terms of disease-free survival ( $\mathrm{p}=0.013$ and $\mathrm{p}<0.001$ respectively) (Figure 3 ).

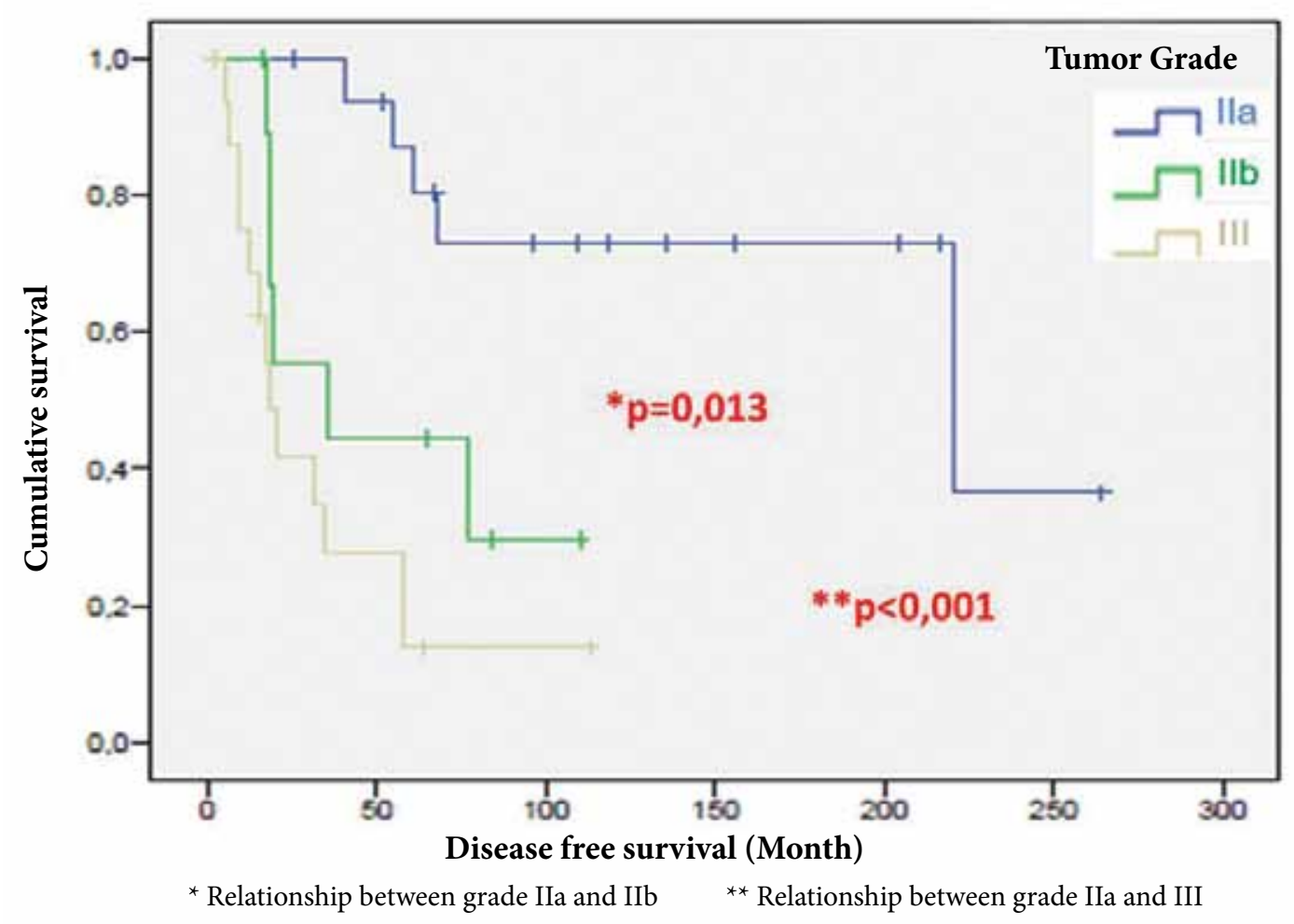

Figure 3: Kaplan-Meier disease-free survival analysis in different tumor grades of synovial sarcoma. 
Table I: Local recurrence, metastasis and survival information of tumor grades

\begin{tabular}{|c|c|c|c|c|}
\hline $\begin{array}{c}\text { Number of cases } \\
(\mathbf{n})=\mathbf{5 0}\end{array}$ & $\begin{array}{c}\text { Local recurrence (-) } \\
\text { and metastasis }(-)\end{array}$ & $\begin{array}{c}\text { Local recurrence } \\
\text { and/or metastasis }(+)\end{array}$ & $\begin{array}{c}\text { Alive } \\
(\mathbf{n}=\mathbf{3 2})\end{array}$ & $\begin{array}{c}\text { Exitus } \\
(\mathbf{n}=\mathbf{1 8})\end{array}$ \\
\hline Grade IIa & $60 \%(\mathrm{n}=12)$ & $17 \%(\mathrm{n}=5)$ & $53 \%(\mathrm{n}=17)$ & - \\
\hline Grade IIb & $20 \%(\mathrm{n}=4)$ & $23 \%(\mathrm{n}=7)$ & $22 \%(\mathrm{n}=7)$ & $22 \%(\mathrm{n}=4)$ \\
\hline Grade III & $20 \%(\mathrm{n}=4)$ & $60 \%(\mathrm{n}=18)$ & $25 \%(\mathrm{n}=8)$ & $78 \%(\mathrm{n}=14)$ \\
\hline
\end{tabular}

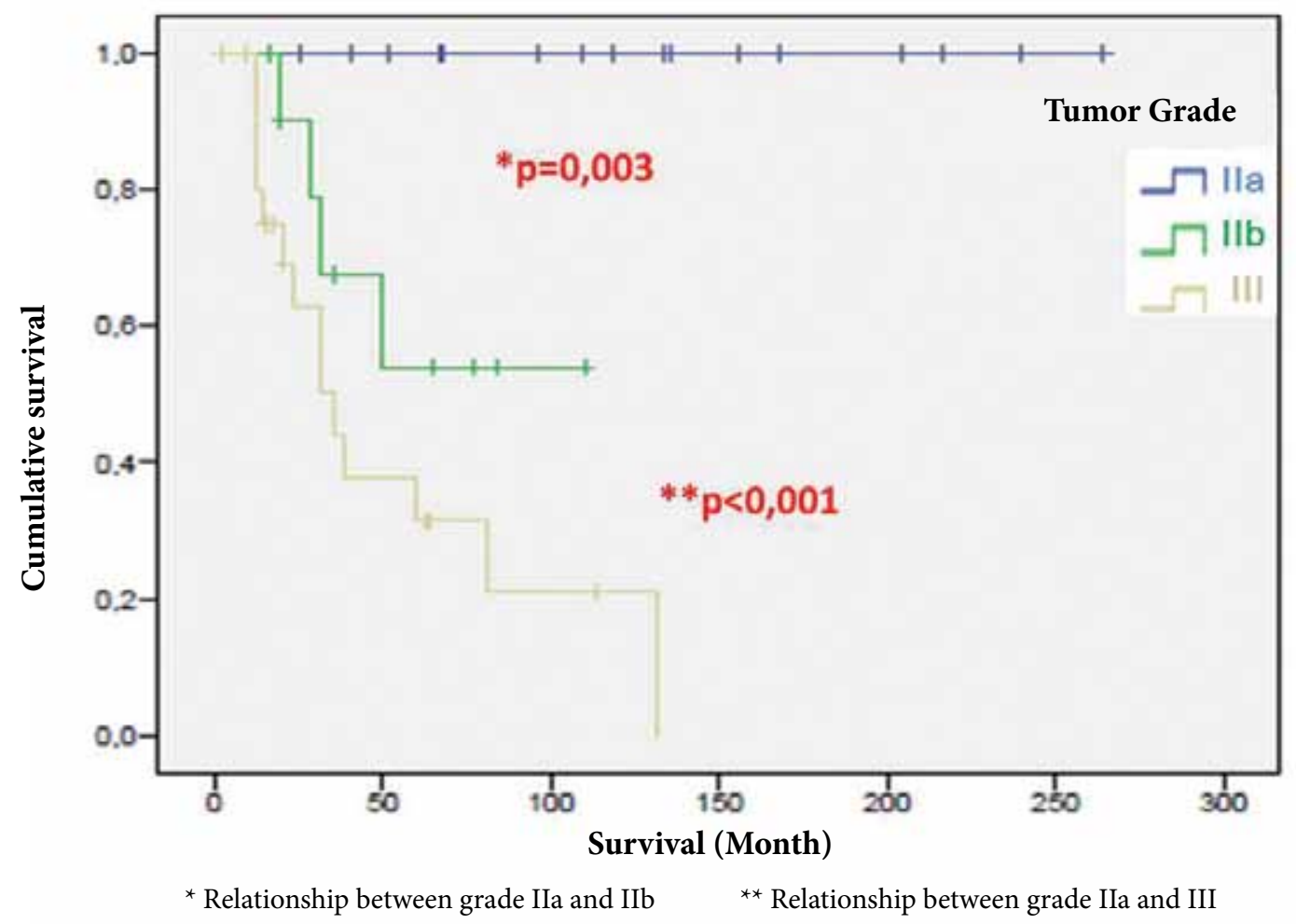

Figure 4: Kaplan-Meier survival analysis in different tumor grades of synovial sarcoma.

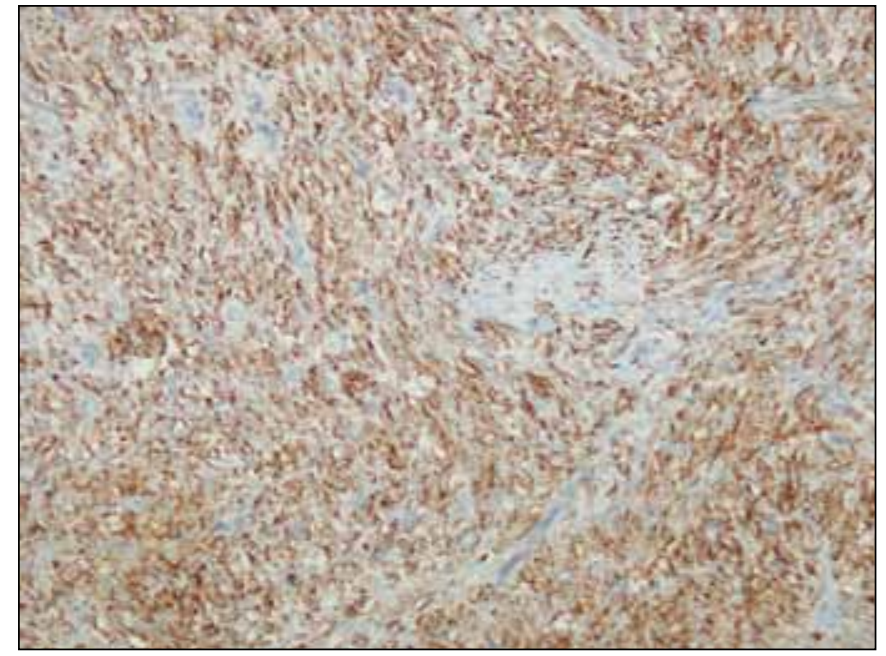

Figure 5: Cytoplasmic bcl-2 positivity in synovial sarcoma (bcl-2; $\mathrm{x} 100)$.
While disease-free survival duration was 159 months in the grade II group (grade IIa + IIb) it was 36 months in the grade III group. The difference between grade II and III was significant in terms of disease-free survival $(p<0.001)$. No statistically significant difference was found between grade IIb and grade III in terms of disease-free survival $(p=0.13)$. A statistically significant difference was found between grade IIa and grade IIb and between grade IIa and grade III in terms of survival ( $\mathrm{p}=0.003$ and $\mathrm{p}<0.001$ respectively) (Figure 4). The difference between grade II and III in terms of survival was significant $(p<0.001)$. No significant difference was found between grade IIb and III regarding survival $(\mathrm{p}=0.15)$. The grade-related metastasis, recurrence, and survival information of the cases are presented in Table I. 


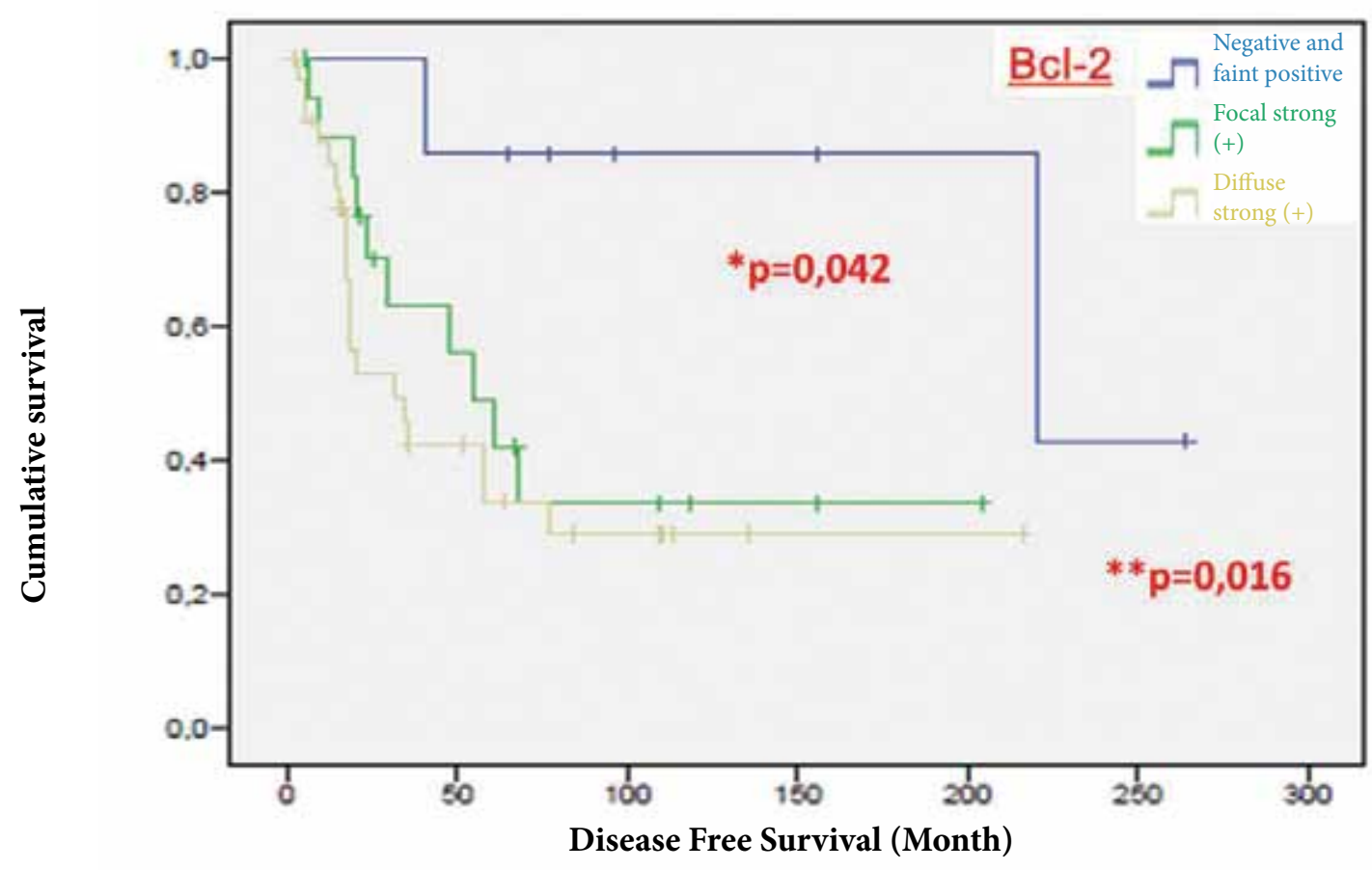

*The relationship between the bcl-2 negative and faint positive groups

${ }^{* *}$ The relationship between the bcl-2 negative and faint positive groups and between the diffuse strong positive groups

Figure 6: Kaplan-Meier disease-free survival analysis with bcl-2 immunoexpression in synovial sarcoma.

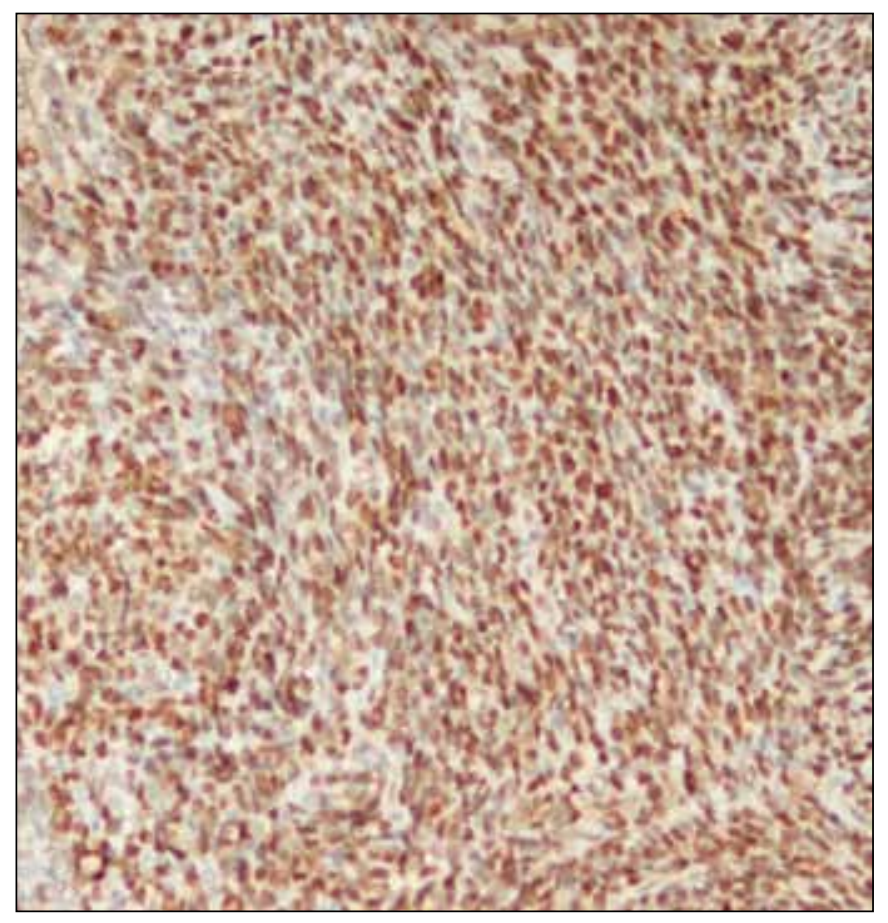

Figure 7: Nuclear c-myc positivity in synovial sarcoma (myc, $\mathrm{x} 200)$.
Bcl-2 was negative or faint positive in 9, focal strong positive in 21 and diffuse strong positive in 35 of 65 patients with follow-up (Figure 5). The Bcl-2 positivity distribution and prognosis relationship is provided in Table II. The relationship between the bcl-2 negative and faint positive groups and between the focal strong positive and diffuse strong positive groups was statistically significant in terms of disease-free survival ( $\mathrm{p}=0.042$ and $\mathrm{p}=0.016$ respectively) (Figure 6).

C-myc was negative in 25, cytoplasmic positive in 23 and nuclear positive in 17 of 65 cases with follow-up (Figure 7). C-myc positivity distribution and the relationship with prognosis is provided in Table II. The relationship between c-myc negative and cytoplasmic positive cases in terms of disease-free survival and between c-myc negative and nuclear positive cases in terms of survival was statistically significant ( $\mathrm{p}=0.05$ and $\mathrm{p}=0.043$ respectively) (Figure 8 ).

Survivin was negative in 23, nuclear positive in 18 and cytoplasmic positive in 24 of 65 cases with follow-up (Figure 9). The relationship between survivin expression and prognosis was not statistically significant (Table II). 


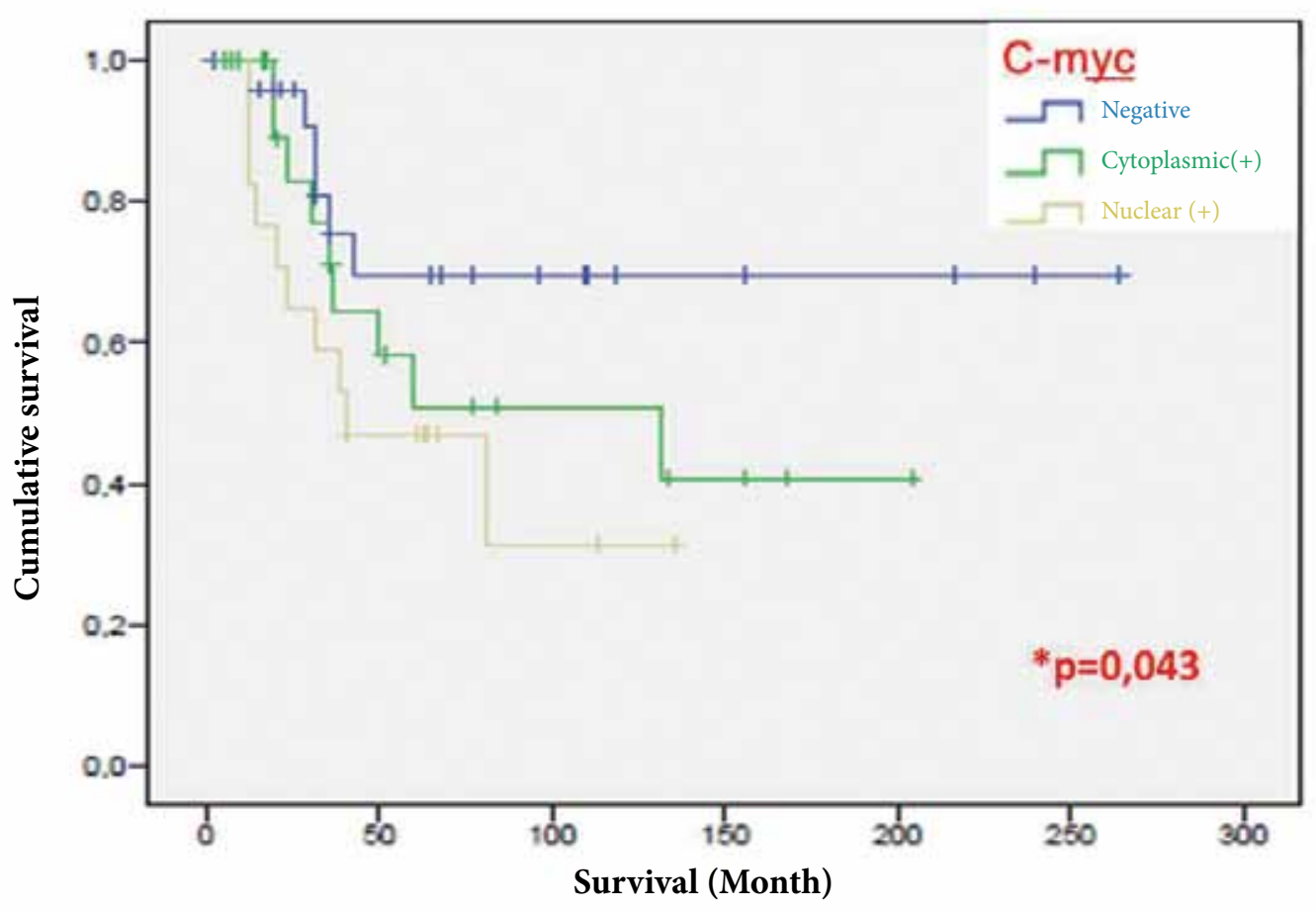

${ }^{\star}$ Relationship between the c-myc negative and nuclear positive cases

Figure 8: Kaplan-Meier survival analysis with c-myc immunoexpression in synovial sarcoma.

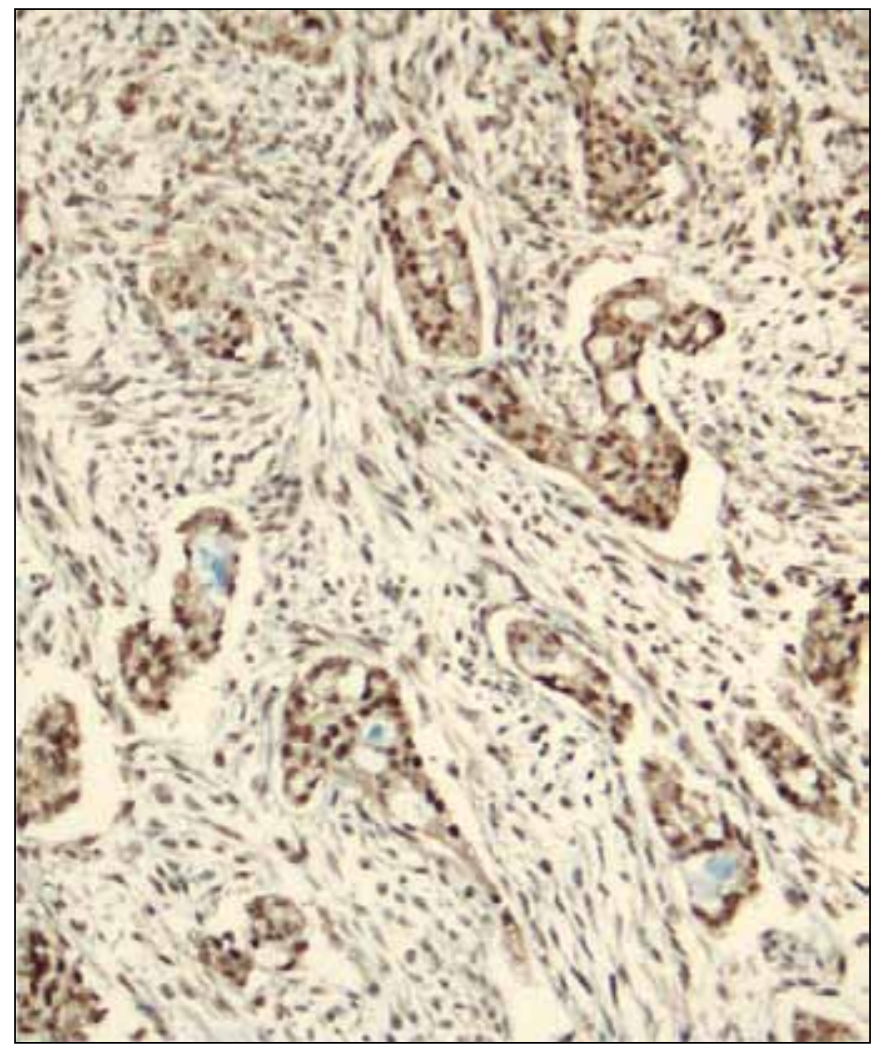

Figure 9: Stronger nuclear survivin positivity in the epithelial areas in synovial sarcoma (survivin, x200).

\section{DISCUSSION}

Synovial sarcoma basically has the appearance of spindle cell sarcoma, but shows epithelial differentiation at the morphological level as well as immunophenotypically. Similar to the literature, about three-quarters of the cases in our study consisted of the monophasic fibrous type. Various findings have been reported in the literature in terms of the relationship between the histologic type of synovial sarcoma cases (monophasic fibrous type, biphasic type) and prognosis $(19,20)$. Although our findings were not statistically significant, the prognosis of the biphasic subtype was a bit worse than the monophasic fibrous type. Local recurrence and/or metastasis were detected in all four poorly differentiated synovial sarcoma cases, confirming aggressive behavior similar to other sources.

Synovial sarcomas are usually aggressive tumors and the five-year survival rate has been reported as $36 \%$ to $76 \%$ and the 10 -year survival rate as $20 \%$ to $63 \%$ in various studies (1,6-11). The five-year survival rate was $57 \%$, and the $10-$ year survival rate $48 \%$ in our study, confirming the literature information that synovial sarcomas are aggressive tumors.

Marked tumor necrosis in the synovial sarcoma and high mitotic activity (> 10 mitosis/10 HPF) have been reported as negative prognostic factors $(15,16)$. The mitotic index 
Table II: bcl-2, c-myc and survivin positivity and relationship with prognosis in synovial sarcoma cases

\begin{tabular}{|c|c|c|c|c|c|c|c|}
\hline & $\begin{array}{l}\text { Disease- } \\
\text { free } \\
\text { survival } \\
\text { (months) }\end{array}$ & $\begin{array}{c}\text { Survival } \\
\text { (months) }\end{array}$ & $\begin{array}{c}\text { Recurrence } \\
\text { or } \\
\text { metastasis - } \\
\text { (26 cases) }\end{array}$ & $\begin{array}{c}\text { Recurrence } \\
\text { or } \\
\text { metastasis + } \\
\text { (39 cases) }\end{array}$ & $\begin{array}{c}\text { Alive } \\
(40 \text { cases })\end{array}$ & $\begin{array}{c}\text { Dead } \\
(25 \text { cases })\end{array}$ & \\
\hline \multicolumn{8}{|l|}{ Bcl-2 } \\
\hline $\begin{array}{l}\text { Negative and Focal faint }+ \\
(9 \text { cases })\end{array}$ & $211 \pm 29$ & $213 \pm 11$ & $5(56 \%)$ & $4(44 \%)$ & $7(78 \%)$ & $2(22 \%)$ & \\
\hline Focal strong $+(21$ cases $)$ & $93 \pm 21$ & $132 \pm 21$ & $8(38 \%)$ & $13(62 \%)$ & $14(67 \%)$ & $7(33 \%)$ & ${ }^{*} \mathrm{p}=0,042$ \\
\hline Diffuse strong $+(35$ cases $)$ & $82 \pm 17$ & $100 \pm 18$ & $13(37 \%)$ & $22(63 \%)$ & $19(54 \%)$ & $16(46 \%)$ & ${ }^{* *} \mathrm{p}=0,016$ \\
\hline \multicolumn{8}{|l|}{ C-myc } \\
\hline Negative ( 25 cases $)$ & $149 \pm 25$ & $193 \pm 24$ & $14(56 \%)$ & $11(44 \%)$ & $19(76 \%)$ & $6(24 \%)$ & \\
\hline Cytoplasmic $+(23$ cases $)$ & $73 \pm 20$ & $114 \pm 20$ & $8(35 \%)$ & $15(65 \%)$ & $14(61 \%)$ & $9(39 \%)$ & $¥ p=0,05$ \\
\hline Nuclear+ (17 cases $)$ & $59 \pm 13$ & $67 \pm 13$ & $4(24 \%)$ & $13(76 \%)$ & $7(41 \%)$ & $10(59 \%)$ & $¥ ¥ \mathrm{p}=0,043$ \\
\hline \multicolumn{8}{|l|}{ Survivin } \\
\hline Negative (23 cases) & $115 \pm 25$ & $158 \pm 27$ & $9(39 \%)$ & $14(61 \%)$ & $15(65 \%)$ & $8(35 \%)$ & \\
\hline Nuclear $+(18$ cases $)$ & $57 \pm 10$ & $94 \pm 14$ & $8(44 \%)$ & $10(56 \%)$ & $12(67 \%)$ & $6(33 \%)$ & $\aleph \mathrm{p}=0,95$ \\
\hline Cytoplasmic + (24 cases $)$ & $79 \pm 15$ & $97 \pm 15$ & $9(38 \%)$ & $15(62 \%)$ & $13(54 \%)$ & $1146 \%)$ & $\aleph \aleph p=0,51$ \\
\hline
\end{tabular}

${ }^{*}$ Relationship of bcl-2 negative and focal faint positive and focal strong positive cases with disease-free survival ${ }^{\star *}$ Relationship of bcl- 2 negative and focal faint positive and diffuse strong positive cases with disease-free survival.

$¥$ Relationship of c-myc negative and cytoplasmic positive cases with disease-free survival, ¥¥ Relationship of c-myc negative and nuclear positive cases with survival

$\aleph$ Relationship of survivin negative and nuclear + cases with disease-free survival, $\boldsymbol{\aleph}$ Relationship of survivin negative and cytoplasmic positive cases with survival.

and the necrosis status of the tumor was associated with survival and disease-free survival and this relationship was statistically significant in our study. The relationship between the tumor grade (where necrosis and mitotic index are used as parameters) and the prognosis was markedly statistically significant. The relationship between the tumor grade and prognosis in synovial sarcoma cases has been reported in the literature $(8,21)$. The differences in prognosis between grade II and III cases are a well-known finding. We divided grade II cases into two groups as IIa and IIb according to the mitosis and necrosis status and found no statistically significant difference between them in terms of prognosis. Grade IIb was found closer to grade III regarding prognosis.

Cytokeratin 7 is reported to react positively in synovial sarcoma cases (2). One study evaluated synovial sarcoma cases containing all subtypes and reported the staining rates for cytokeratin 7 in the biphasic, monophasic fibrous and poorly differentiated types as $100 \%, 79 \%$ and $50 \%$ respectively (22). Cases found to be positive for pancytokeratin or EMA were included in this study. Positivity with cytokeratin 7 was found in two of three cases.
The bcl-2 gene plays an important role in pathophysiological processes as a mechanism ensuring the elimination of unwanted apoptotic cells. The interruption of this function creates one of the tumor development mechanisms. The bcl-2 oncogene and the protein it encodes have been reported for the first time in follicular lymphoma cases (23). The bcl-2 gene and the protein product prolong the life of the cell, and the correlation between the expression level and prognosis has been studied in various tumors. For example, a correlation has been found between bcl-2 expression and unfavorable histological parameters and clinical course in tumors such as neuroblastoma and Ewing sarcoma (24). Bcl-2 positivity in synovial sarcoma (highly diffuse positive) is a well-known finding $(6,25-27)$ but its relationship with prognosis is unclear (13). A correlation has recently been found between the bcl-2 m-RNA level and immunohistochemical expression severity and diffuseness in 32 synovial sarcoma cases where the SS18/SSX1 or SS18/SSX2 fusion gene was detected on PCR. A higher metastasis rate and shorter life was found in cases with more bcl-2 immunohistochemical expression in the same study but this finding was not statistically significant (13). The disease-free survival duration was significantly shorter 
in cases showing strong positively bcl-2 staining than in bcl-2 negative and focal faint positive cases in our study. Although bcl-2 staining is not specific for the diagnosis of synovial sarcoma it may be contribute to determining the diagnosis in addition it may have prognostic value. However, we believe this finding needs to be verified in larger series due to the low number of negative and focal faint positive cases compared in our study.

The c-myc protein functions as a transcription factor ensuring the regulation of critical cellular processes such as cell cycle regulation, cell differentiation, apoptosis, adhesion and migration $(28,29)$. Contrary to the regulated myc expression during normal cell proliferation, the expression of myc protein is commonly sustained and sometimes excessive in tumors. This can lead to continuous transcription of critical target genes and subsequently to neoplastic transformation. Oncogenic activation occurs through gene amplification and chromosomal translocation. C-myc expression has been reported to be associated with a poor prognosis in solid tumors such as synovial sarcoma, osteosarcoma, leiomyosarcoma, and liposarcoma (30). C-myc overexpression has also been identified in high-grade liposarcoma, chondrosarcoma, and uterine leiomyosarcoma (31). A study evaluated 28 cases that were histologically and immunohistochemically diagnosed with leiomyosarcoma. C-myc expression was found to be associated with survival and c-myc was identified as an independent prognostic factor in multivariate analysis (32). The relationship between c-myc and prognosis was investigated in 27 synovial sarcoma cases with at least 24 months follow-up and c-myc nuclear positivity was reported to be a negative prognostic indicator (33). Although c-myc is a marker expected to give a nuclear reaction, it can also show cytoplasmic staining (34). There was a statistically significant relationship between c-myc negative cases and the cytoplasmic and/or nuclear positive cases in this study. Survival and disease-free survival duration was found to be longer in c-myc negative cases. We think that this finding should be verified with larger series as the statistical significance was low.

Survivin is a member of the apoptosis inhibitor family and shows its effect by inhibiting caspase activity. Survivin can be detected in the cytoplasm and/or nucleus of tumor cells. Cytoplasmic expression of survivin is reported to be associated with apoptosis inhibition and control of cell life and its nuclear expression with facilitating cell proliferation. Some studies report that nuclear positivity is associated with the prognosis while others report that both nuclear and cytoplasmic positivity is associated with the prognosis $(16,35,36)$. There are some studies indicating the survivin expression is associated with the prognosis in osteosarcoma, leiomyosarcoma and synovial sarcoma $(16,35)$. Survivin expression was linked to the prognosis in osteosarcomas and nuclear positivity was found to result in long-term survival (35). Both nuclear and cytoplasmic immunohistochemical positivity of survivin have been reported to be independent prognostic factors for synovial sarcoma and leiomyosarcoma in 24 leiomyosarcoma and 26 synovial sarcoma cases (36). The survival or disease-free survival durations in survivin-negative cases were longer than the survivin-positive cases in our study but this was not statistically significant.

In conclusion, necrosis and proliferative activity, and tumor grade (where directly associated with these two parameters) are important for predicting possible aggressive behavior. We divided grade II synovial sarcoma cases into two subgroups unlike the general approach reported in the literature and found significant difference between these two subgroups in terms of prognosis. Our results indicate that cases with 10 or more mitoses on $10 \mathrm{HPF}$ or containing necrosis (grade IIb) show a relatively more aggressive course (prognosis closer to grade III) or in other words cases without necrosis and less than 10 mitoses per $10 \mathrm{HPF}$ (grade IIa) have a relatively better prognosis. Furthermore, this finding highlights the importance of conventional parameters such as mitosis and necrosis. We determined that the immunohistochemical markers bcl-2 and c-myc may have prognostic significance in synovial sarcoma cases but the statistical value of the relationship between these findings and the prognosis was borderline and should be verified with larger series.

\section{ACKNOWLEDGMENTS}

We thank Assistant Professor Dr. Timur Köse, a faculty member in Ege University Department of Biostatistics and Medical Informatics, for his assistance in the statistical evaluation of this study.

\section{CONFLICT of INTEREST}

This study was supported by the Ege University Rectorate, Commission of Scientific Research Projects (Project 2010 TIP 071).

\section{REFERENCES}

1. Weiss SW, Golgblum JR. Synovial sarcoma. In: Enzinger FM, Weiss SW, editors. Soft tissue tumors. 5th ed. St. Louis: CV Mosby; 2008.1161-221. 
2. Olsen SH, Thomas DG, Lucas DR. Cluster analysis of immunohistochemical profiles in synovial sarcoma, malignant peripheral nerve sheath tumor, and Ewing sarcoma. Mod Pathol. 2006;19:659-68.

3. Terry J, Saito T, Subramanian S, Ruttan C, Antonescu CR, Goldblum JR, Downs-Kelly E, Corless CL, Rubin BP, van de Rijn M, Ladanyi M, Nielsen TO. TLE1 as a diagnostic immunohistochemical marker for synovial sarcoma emerging from gene expression profiling studies. Am J Surg Pathol. 2007;31:240-6.

4. Kosemehmetoglu K, Vrana JA, Folpe AL. TLE1 expression is not specific for synovial sarcoma: A whole section study of $163 \mathrm{soft}$ tissue and bone neoplasms. Mod Pathol. 2009;22:872-8.

5. Sandberg AA, Bridge JA. Updates on the cytogenetics and molecular genetics of bone and soft tissue tumors. Synovial sarcoma. Cancer Genet Cytogenet. 2002;133: 1-23.

6. Spillane AJ, A'Hern R, Judson IR, Fisher C, Thomas JM. Synovial sarcoma: A clinicopathologic, staging, and prognostic assessment. J Clin Oncol. 2000;18:3794-803.

7. Ladanyi M, Antonescu CR, Leung DH, Woodruff JM, Kawai A, Healey JH, Brennan MF, Bridge JA, Neff JR, Barr FG, Goldsmith JD, Brooks JS, Goldblum JR, Ali SZ, Shipley J, Cooper CS, Fisher C, Skytting B, Larsson O. Impact of SYT-SSX fusion type on the clinical behavior of synovial sarcoma: A multi-institutional retrospective study of 243 patients. Cancer Res. 2002; 62:135-40.

8. Brecht IB, Ferrari A, Int-Veen C, Schuck A, Mattke AC, Casanova M, Bisogno G, Carli M, Koscielniak E, Treuner J. Grossly-resected synovial sarcoma treated by the German and Italian Pediatric Soft Tissue Sarcoma Cooperative Groups: Discussion on the role of adjuvant therapies. Pediatr Blood Cancer. 2006; 46:11-7.

9. Trassard $M$, Le Doussal V, Hacène $K$, Terrier $P$, Ranchère D, Guillou L, Fiche M,Collin F, Vilain MO, Bertrand G, Jacquemier J, Sastre-Garau X, Bui NB, Bonichon F, Coindre JM. Prognostic factors in localized primary synovial sarcoma: A multicenter study of 128 adult patients. J Clin Oncol. 2001;19:525-34.

10. Spurrell EL, Fisher C, Thomas JM, Judson IR. Prognostic factors in advanced synovial sarcoma: An analysis of 104 patients treated at the Royal Marsden Hospital. Ann Oncol. 2005;16:437-44.

11. Bergh P, Meis-Kindblom JM, Gherlinzoni F, Berlin O, Bacchini P, Bertoni F, Gunterberg B, Kindblom LG. Synovial sarcoma: Identification of low and high risk groups. Cancer. 1999;85: 2596-607.

12. Fletcher CDM, Bridge JA, Hogendoorn PCW, Mertens F (Eds): Who Health Organization Classification of Tumors Pathology and Genetics of Tumors of Soft Tissue and Bone. Lyon: IARC Press; 2013. 213-5.

13. Krsková L, Kalinová M, Brízová $H$, Mrhalová $M$, Sumerauer D, Kodet R. Molecular and immunohistochemical analyses of BCL2, KI-67, and cyclin D1 expression in synovial sarcoma. Cancer Genet Cytogenet. 2009;193:1-8.

14. Tsiatis AC, Herceg ME, Keedy VL, Halpern JL, Holt GE, Schwartz HS, Cates JM. Prognostic significance of c-Myc expression in soft tissue leiomyosarcoma. Mod Pathol. 2009;22:1432-8.
15. Shen J, Scotlandi K, Baldini N, Manara MC, Benini S, Cerisano V, Picci P, Serra M. Prognostic significance of nuclear accumulation of $\mathrm{c}$-myc and $\mathrm{mdm} 2$ proteins in synovial sarcoma of the extremities. Oncology. 2000;58:253-60.

16. Kappler M, Kotzsch M, Bartel F, Füssel S, Lautenschläger C, Schmidt U, Würl P, Bache M, Schmidt H, Taubert H, Meye A. Elevated expression level of survivin protein in soft-tissue sarcomas is a strong independent predictor of survival. Clin Cancer Res. 2003;9:1098-104.

17. Taubert H, Heidenreich C, Holzhausen HJ, Schulz A, Bache M, Kappler M, Eckert AW, Würl P, Melcher I, Hauptmann K, Hauptmann S, Schaser KD. Expression of survivin detected by immunohistochemistry in the cytoplasm and in the nucleus is associated with prognosis of leiomyosarcoma and synovial sarcoma patients. BMC Cancer. 2010;10:65.

18. Coindre JM, Trojani M, Contesso G, David M, Rouesse J, Bui NB, Bodaert A, De Mascarel I, De Mascarel A, Goussot JF. Reproducibility of a histopathologic grading system for adult soft tissue sarcoma. Cancer. 1986;58:306-9.

19. Kawai A, Woodruff J, Healey JH, Brennan MF, Antonescu CR, Ladanyi M. SYT-SSX gene fusion as a determinant of morphology and prognosis in synovial sarcoma. N Engl J Med. 1998;338: 153-60.

20. Cagle LA, Mirra JM, Storm FK, Roe DJ, Eilber FR. Histologic features relating to prognosis in synovial sarcoma. Cancer. 1987;59:1810-4.

21. Guillou L, Benhattar J, Bonichon F, Gallagher G, Terrier P, Stauffer E, Somerhausen Nde S, Michels JJ, Jundt G, Vince DR, Taylor S, Genevay M, Collin F, Trassard M, Coindre JM. Histologic grade but not SYT-SSX fusion type is an important prognostic factor in patients with synovial sarcoma: A multicenter retrospective analysis. J Clin Oncol. 2004;22: 4040-50.

22. Miettinen M, Limon J, Niezabitowski A, Lasota J. Patterns of keratin polypeptides in 110 biphasic, monophasic, and poorly differentiated synovial sarcomas. Virchows Arch. 2000;437: 275-83.

23. Chen-Levy Z, Nourse J, Cleary ML. The bcl-2 candidate protooncogene product is a 24-kilodalton integral-membrane protein highly expressed in lymphoid cell lines and lymphomas carrying the $t(14 ; 18)$ translocation. Mol Cell Biol. 1989;9:701-10.

24. Castle VP, Heidelberger KP, Bromberg J, Ou X, Dole M, Nuñez G. Expression of the apoptosis-suppressing protein bcl-2, in neuroblastoma is associated with unfavorable histology and N-myc amplification. Am J Pathol. 1993;143:1543-50.

25. Hirakawa N, Naka T, Yamamoto I, Fukuda T, Tsuneyoshi M. Overexpression of bcl-2 protein in synovial sarcoma: A comparative study of other soft tissue spindle cell sarcomas and an additional analysis by fluorescence in situ hybridization. Hum Pathol. 1996;27:1060-5.

26. Mancuso T, Mezzelani A, Riva C, Fabbri A, Dal Bo L, Sampietro G, Perego P, Casali P, Zunino F, Sozzi G, Pierotti MA, Pilotti S. Analysis of SYT-SSX fusion transcripts and bcl-2 expression and phosphorylation status in synovial sarcoma. Lab Invest. 2000;80:805-13. 
27. Kawauchi S, Fukuda T, Oda Y, Saito T, Oga A, Takeshita M, Yokoyama K, Chuman H, Iwamoto Y, Sasaki K, Tsuneyoshi M. Prognostic significance of apoptosis in synovial sarcoma: Correlation with clinicopathologic parameters, cell proliferative activity, and expression of apoptosis-related proteins. Mod Pathol. 2000;13:755-65.

28. Knoepfler PS. Myc goes global: New tricks for an old oncogene. Cancer Res. 2007;67:5061-3.

29. Pelengaris S, Khan M, Evan G. c-MYC: More than just a matter of life and death. Nat Rev Cancer. 2002;2:764-76.

30. Scionti I, Michelacci F, Pasello M, Hattinger CM, Alberghini M, Manara MC, Bacci G, Ferrari S, Scotlandi K, Picci P, Serra M. Clinical impact of the methotrexate resistance-associated genes C-MYC and dihydrofolate reductase (DHFR)in high-grade osteosarcoma. Ann Oncol. 2008;19:1500-8.

31. Barrios C, Castresana JS, Kreicbergs A. Clinicopathologic correlations and short-term prognosis in musculoskeletal sarcoma with c-myc oncogene amplification. Am J Clin Oncol. 1994;17:273-6.
32. Tsiatis AC, Herceg ME, Keedy VL, Halpern JL, Holt GE, Schwartz HS, Cates JM. Prognostic significance of c-myc expression in soft tissue leiomyosarcoma. Mod Pathol. 2009;22:1432-8.

33. Shen J, Scotlandi K, Baldini N, Manara MC, Benini S, Cerisano V, Picci P, Serra M. Prognostic significance of nuclear accumulation of $\mathrm{c}$-myc and $\mathrm{mdm} 2$ proteins in synovial sarcoma of the extremities. Oncology. 2000;58:253-60.

34. Feller K, Yang S, Tung N, Lee J, Mahalingam M. c-myc in Kaposi's sarcoma: Analyses by fluorescent in situ hybridization and immunohistochemistry. J Eur Acad Dermatol Venereol. 2014;28:120-4.

35. Trieb K, Lehner R, Stulnig T, Sulzbacher I, Shroyer KR. Survivin expression in human osteosarcoma is a marker for survival. Eur J Surg Oncol. 2003;29:379-82.

36. Taubert H, Heidenreich C, Holzhausen HJ, Schulz A, Bache M, Kappler M, Eckert AW, Würl P, Melcher I, Hauptmann K, Hauptmann S, Schaser KD. Expression of survivin detected by immunohistochemistry in the cytoplasm and in the nucleus is associated with prognosis of leiomyosarcoma and synovial sarcoma patients. BMC Cancer. 2010;10:65. 